Relations industrielles

Industrial Relations

\title{
Index - volume $37-1982$
}

Volume 37, numéro 4, 1982

URI : https://id.erudit.org/iderudit/029323ar

DOI : https://doi.org/10.7202/029323ar

Aller au sommaire du numéro

Éditeur(s)

Département des relations industrielles de l'Université Laval

\section{ISSN}

0034-379X (imprimé)

1703-8138 (numérique)

Découvrir la revue

Citer ce document

(1982). Index - volume 37 - 1982. Relations industrielles / Industrial Relations, 37(4), 986-997. https://doi.org/10.7202/029323ar

Tous droits réservés @ Département des relations industrielles de l'Université Laval, 1982
Ce document est protégé par la loi sur le droit d'auteur. L’utilisation des services d'Érudit (y compris la reproduction) est assujettie à sa politique d'utilisation que vous pouvez consulter en ligne.

https://apropos.erudit.org/fr/usagers/politique-dutilisation/ 


\section{INDEX - VOL. $37-1982$}

\section{Index alphabétique des articles}

Action gouvernementale en matière d'égalité de salaire: Canada et États-Unis, L,

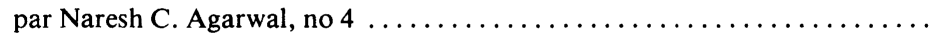

Alienation Among Professional Engineers: A Canadian-American Comparison,

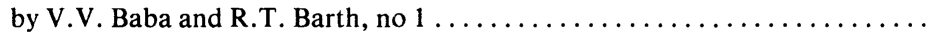

$802-805$

$126-138$

Aliénation parmi les ingénieurs canadiens et américains, Comparaison sur l'intensité de l', par V.V. Baba et R.T. Barth, no $1 \ldots \ldots \ldots \ldots \ldots \ldots \ldots \ldots$

Analyse de la première grève d'un syndicat d'enseignants, $L$ ', par Philip Harris,

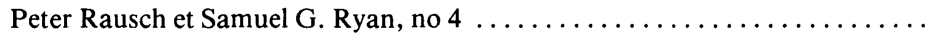

Apprenticeship Training in European Countries. The Lessons for Canada, Klaus

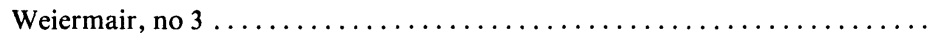

Augmentation de l'emploi dans les services au Canada, L', par Sunder Magun,

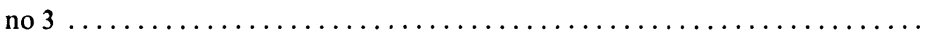

British Columbia: 1945-1975, Strike Activity and Wildcat Strikes in, by E.G.

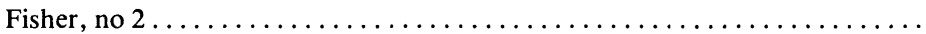

British Evidence, Third Party Conciliation and Trade Union Recognition: Some,

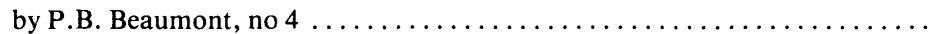

Canada, 1910 à 1980, La part des salaires dans le revenu national au, Gérald

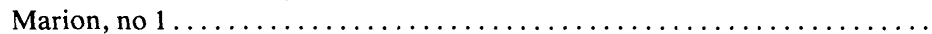

Canada, 1926-1974, Legislative Change and Strike Activity in, by J.A. Frank, Michael J. Kelly and Bruce D. Macnaughton, no $2 \ldots \ldots \ldots \ldots \ldots \ldots$. . . . . .

926-928

$557-573$

$528-555$

284-301

$827-841$

$53-64$

Canada and the U.S., Male-Female Pay Inequity and Public Policy in, by Naresh C. Agarwal, no 4

$780-802$

Canada, Characteristics of Female Union Officers in, by Gary N. Chaison and P.

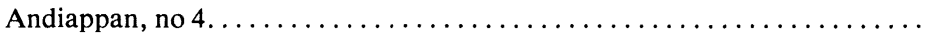

Canada Labour Relations Board Case Management System, The, by Gilles Coulombe, no 4

$941-944$

Canada, L'augmentation de l'emploi dans les services au, par Sunder Magun, no 3

Canada, Le taux de salaire d'acceptation sur les marchés du travail au, par Abrar

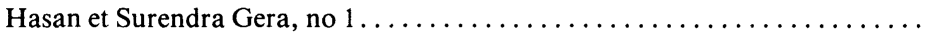

Canada, Partis politiques et croissance des syndicats au, par Dennis R. Maki,

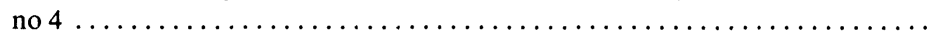

Canada, Political Parties and Trade Union Growth in, by Dennis R. Maki, no 4 ..

Canada: The Current Situation and a Proposal, Labour Market Information in,

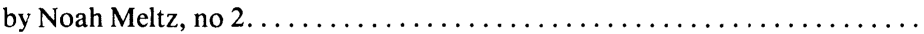

Canada. Theories, Evidence and Policies, Race and Sex Discrimination in Employment in, by Harish C. Jain, no $2 \ldots \ldots \ldots \ldots \ldots \ldots \ldots \ldots \ldots \ldots \ldots \ldots \ldots$

Canadian-American Comparison, Alienation Among Professional Engineers: A,

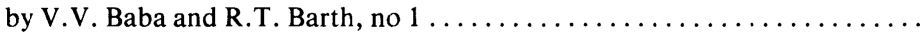

Canadian Labour Congress and Tripartism, The, by Anthony Giles, no $1 \ldots \ldots$. . .

Canadair-I.A.M. Productivity Improvement Plan, The, by David A. Peach,

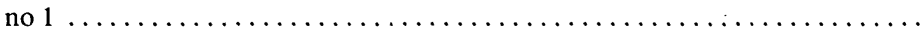

Changements à la législation et évolution des grèves au Canada de 1926 à 1974, par par J.A. Frank, Michael J. Kelly and Bruce D. Macnaughton, no $2 \ldots \ldots \ldots$. 
Characteristics of Female Union Officers in Canada, by Gary N. Chaison and P.

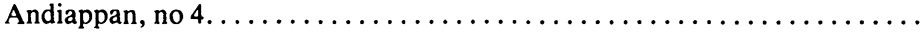

Chômage, l'inflation et les travailleurs étrangers: étude comparative de trois pays

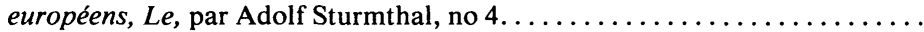

Collective Agreement, Job Evaluation and the, by Jean-Paul Deschênes, no 2 ....

Colombie-Britannique, Grèves et grèves sauvages en, E.G. Fisher, no $2 . \ldots \ldots \ldots$

Comité paritaire: anachronisme ou formule d'avenir, Le, par Gérard P. Latulippe

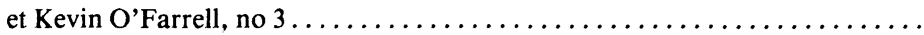

Comparaison sur l'intensité de l'aliénation parmi les ingénieurs canadiens et américains, par V.V. Baba et R.T. Barth, no $1 \ldots \ldots \ldots \ldots \ldots \ldots \ldots \ldots \ldots$

Conciliation and Trade Union Recognition: Some British Evidence, Third Party,

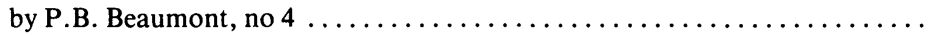

Conciliation par une tierce partie et la reconnaissance des syndicats en Grande-

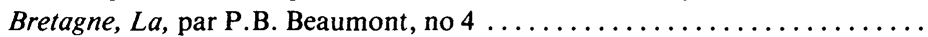

Concurrence dans un contexte de pluralisme syndical. Quelques données sur le

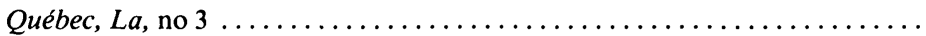

Congrès du travail du Canada et le tripartisme, Le, par Anthony Giles, no $1 . . .$. .

Conseil canadien des relations du travail, Le système de gestion des cas $d u$, par

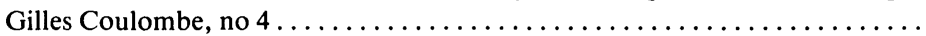

Construction, Les formes d'organisation dans l'industrie de la, par Roger Miller,

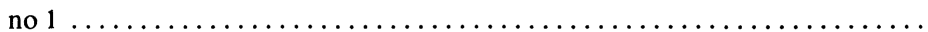

$575-603$

124-126

928-941

$164-177$

Convention collective, L'évaluation des emplois et la, par Jean-Paul Deschênes,

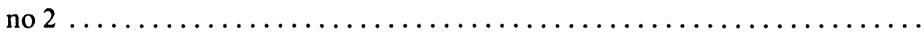

Critique de la théorie des relations professionnelles, par Syed M.A. Hameed,

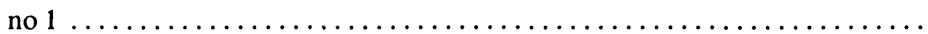

Critique of Industrial Relations Theory, $A$, by Syed M.A. Hameed, no $1 \ldots \ldots$.

Développement des syndicats industriels à Montréal de 1935 à 1945, Le, par Terry

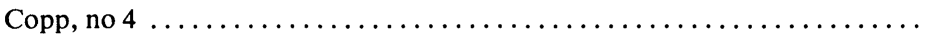

Discrimination dans l'emploi au Canada, Race et sexe et tant qu'objet de, par

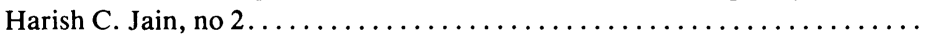

Discrimination in Employment in Canada. Theories Evidence and Policies, Race

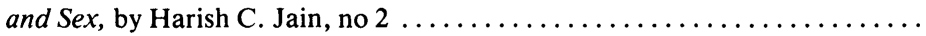

Double modèle de décision pour les spécialistes en formation et en développement,

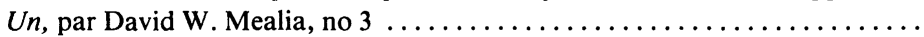

Efficacité des clauses d'indexations des salaires, L', par Jean-Michel Cousineau, Robert Lacroix, Sharon Michaud, Jean-Charles Roy, Jacques Choinard, André Viel et Jean-Marc Robichaud, no $1 \ldots \ldots \ldots \ldots \ldots \ldots \ldots \ldots . . . \ldots \ldots$

Égalité de salaire: Canada et États-Unis, L'action gouvernementale en matière d',

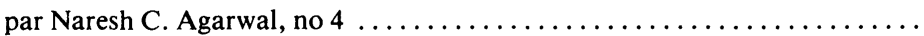

Emploi dans les services au Canada, L'augmentation de l', par Sunder Magun,

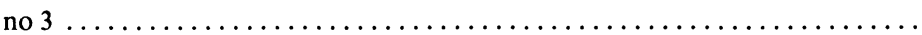

$361-367$

344-361

$668-670$

206-226

$802-805$

$555-557$

Employés de bureau: le cas de la fonction publique québécoise, La santé des, par Alain Vinet, Clermont Bégin et Gilles Thériault, no $4 \ldots \ldots \ldots \ldots \ldots \ldots$

$887-904$

$805-823$ Louis Toupin, Claude Lessard, Roger A. Cormier et Paul Valois, no 4 .....

Enseignants québécois: 1975-1976, La négociation collective chez les fonctionnai-

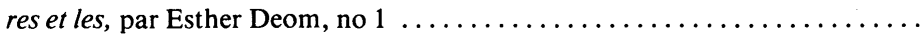

Enseignants, L'analyse de la première grève d'un syndicat, $d$ ', par Philip Harris, Peter Rausch et Samuel G. Ryan, no $4 \ldots \ldots \ldots \ldots \ldots \ldots \ldots \ldots \ldots$

European Countries, Unemployment, Inflation and "Guest Workers": Comparative Study of Three, by Adolf Sturmthal, no $4 \ldots \ldots \ldots \ldots \ldots \ldots$

926-928 
Évaluation des emplois et la convention collective, $L$ ', par Jean-Paul Deschênes,

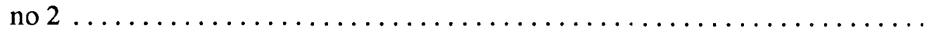

Federal Government and Tripartism, The, by Roy J. Adams, no $3 \ldots \ldots \ldots \ldots$

Female Labour Force Participation Rates Disaggregated by Marital Status, A Time Series Analysis of, by William D. Walsh, no $2 \ldots \ldots \ldots \ldots \ldots \ldots$

Female Union Officers in Canada, Characteristics, of, by Gary N. Chaison and P.

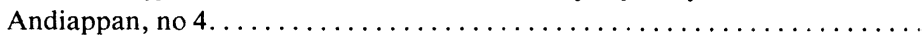

Femme et les postes de direction dans les syndicats, La, par Gary N. Chaison et $\mathrm{P}$.

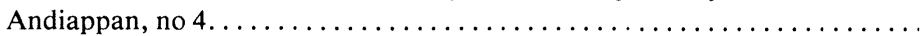

Fonctionnaires et les enseignants québécois: 1975-1976, La négociation collective

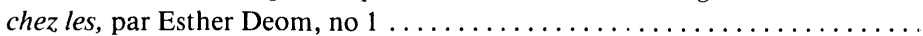

Fonction publique québécoise, La santé des employés de bureau: le cas de la, par Alain Vinet, Clermont Bégin et Gilles Thériault, no $4 \ldots \ldots \ldots \ldots \ldots \ldots$.

Formation et développement, Un double modèle de décision pour les spécialistes

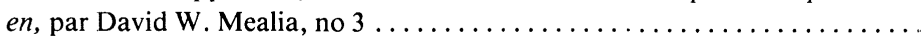

Formation professionnelle dans les pays européens, La, par Klaus Weiermair, no 3

Formes d'organisation dans l'industrie de la construction, Les, par Roger Miller, no 1

Gérard Dion, par Gérard Hébert, no 3

Gouvernement fédéral et le tripartisme, Le, par Roy J. Adams, no $3 \ldots \ldots \ldots \ldots$

Gouvernementale en matière d'égalité de salaire: Canada et États-Unis, L'action, par Naresh C. Agarwal, no 4

Grande-Bretagne, La conciliation par une tierce partie et la reconnaissance des syndicats en, par P.B. Beaumont, no 4 .

802-805

841-843

Grèves au Canada, Changements à la législation et évolution des, par J.A. Frank, Michael J. Kelly et Brude D. Macnaughton, no $2 \ldots \ldots \ldots \ldots \ldots \ldots \ldots$

Grève d'un syndicat d'enseignants, L'analyse de la première, par Philip Harris, Peter Rausch et Samuel G. Ryan, no $4 \ldots \ldots \ldots \ldots \ldots \ldots \ldots \ldots \ldots \ldots$

Grèves et grèves sauvages en Colombie-Britannique, par E.G. Fisher, no 2 .......

Grievance Procedures in United Nations Secretariats, Individual, by Yves

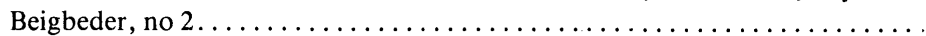

Groupes semi-autonomes de production: hypothèse pour l'analyse du cas Rushton, La stratégie syndicale face aux, par Michel Brossard, no 3 .......

“Guest Workers": Comparative Study of Three European Countries, Unemployment, Inflation and, by Adolf Sturmthal, no $4 \ldots \ldots \ldots \ldots \ldots \ldots$.

Health of Office Workers in the Québec Civil Service: An Empirical Study, by Alain Vinet, Clermont Bégin et Gilles Thériault, no $4 \ldots \ldots \ldots \ldots \ldots \ldots$.

Heures de travail, La nature des besoins chez les gens en dehors des, par M. Jamal,

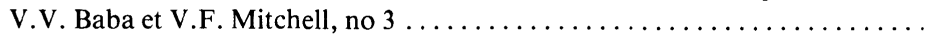

$281-284$

926-928

301-302

$328-342$

$670-684$

$739-762$

904-905

$632-634$

Indexations des salaires, L'efficacité des clauses d', par Jean-Michel Cousineau, Robert Lacroix, Sharon Michaud, Jean-Charles Roy, Jacques Chouinard, André Viel et Jean-Marc Robichaud, no $1 \ldots \ldots \ldots \ldots \ldots \ldots \ldots \ldots . . \ldots . \ldots$

Individual Grievance Procedures in United Nations Secretariats, by Yves

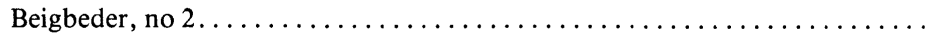

Industrial Relations: A Paradigmatic Analysis, by Stanley Young, no $1 . \ldots \ldots$. . Industrial Relations and the Challenges of the 1980's, Francis Blanchard, no 1.... Industrial Relations Theory, A critique of, by Syed M.A. Hameed, no $1 \ldots \ldots \ldots$. Industrial Unions in Montréal 1935-1945, The Rise of, by Terry Copp, no 4 ...... Ineffectiveness in Teacher Bargaining: The Anatomy of a First Strike, by Philip Harris, Peter Rausch and Samuel G. Ryan, no $4 \ldots \ldots \ldots \ldots \ldots \ldots$ 
Inflation: A Survey Article, The Role of Unions in, by C.W. Williams, no 3..... Inflation and "Guest Workers": Comparative Study of Three European

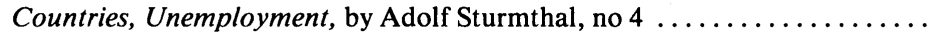
Inflation et les travailleurs étrangers: étude comparative de trois pays européens,

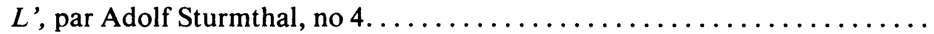
Inflation, Les syndicats et l', par C.G. Williams, no $3 \ldots \ldots \ldots \ldots \ldots \ldots \ldots$ Ingénieurs canadiens et américains, Comparaison sur l'intensité de l'aliénation parmi les, par V.V. Baba et R.T. Barth, no $1 \ldots \ldots \ldots \ldots \ldots \ldots \ldots \ldots$ Job Evaluation and the Collective Agreement, by Jean-Paul Deschênes, no 2.....

Key Points of a Proposed Wage Policy for the Public and Para-Public Sectors, by

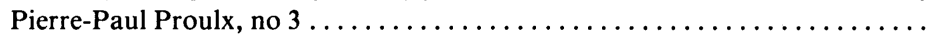

Labour Market Information in Canada: The Current Situation and a Proposal, by

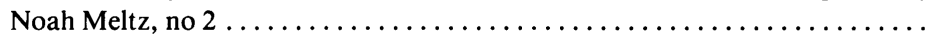

Labour Markets, Reservation Wages in Canadian, Abrar Hasan and Surendra

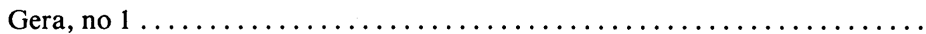

Législation et évolution des grèves au Canada, Changements à la, par J.A. Frank, Michael J. Kelly et Bruce D. Macnaughton, no $2 \ldots \ldots \ldots \ldots \ldots \ldots \ldots$

Legislative Change and Strike Activity in Canada, 1926-1974, by J.A. Frank, Michael J. Kelly and Bruce D. Macnaughton, no $2 \ldots \ldots \ldots \ldots \ldots \ldots$

Macro/Micro Decision Model for the Training and Development Specialist, A, by David W. Mealia, no 3.

656-668

Main-d'oeuvre féminine et le statut matrimonial, Le taux d'activité de la, par

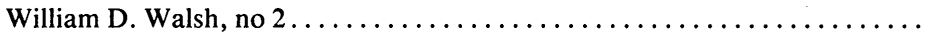

Male-Female Pay Inequity and Public Policy in Canada and the U.S., by Naresh C. Agarwal, no 4

$780-802$

Marchés du travail au Canada, Le taux de salaire d'acceptation sur les, par Abrar

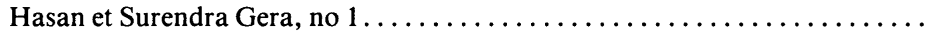
Montréal 1935-1945, The Rise of Industrial Unions in, by Terry Copp, no 4 ...... Montréal de 1935 à 1945, Le développement des syndicats industriels à, par Terry Copp, no 4

Nations Unies, Les voies de recours individuel dans les secrétariats des, par Yves

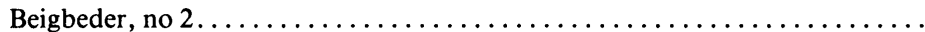

Nature des besoins chez les gens en dehors des heures de travail, La, par M. Jamal,

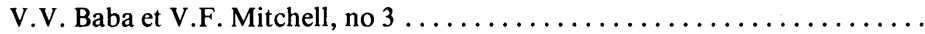
Nature of Need Structure in Nonwork, The, by M. Jama, V.V. Baba and V.F.

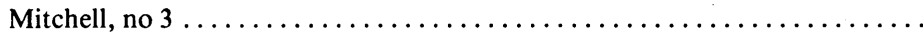

Need Structure in Nonwork, The nature of, by M. Jamal, V.V. Baba and V.F.

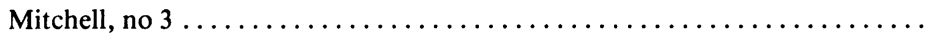

Négociation collective chez les fonctionnaires et les enseignants québécois: 1975-

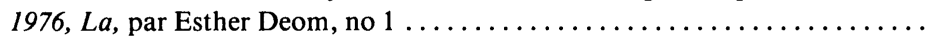

Négociation des secteurs public et para-public. Bilan et perspectives, Le régime québécois de, par Roch Bolduc, Lucien Bouchard et Gérard Hébert, no 2 .... Nonwork, The Nature of Need Structure in, by M. Jamal, V.V. Baba and V.F.

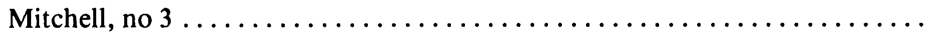

Note of the Critical Dimensions of the Union Merger Process, A., by Gary N.

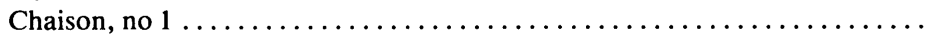

Office Workers in the Québec Civil Service: An Empirical Study, Health of, by Alain Vinet, Clermont Bégin et Gilles Thériault, no $4 \ldots \ldots \ldots \ldots \ldots \ldots$

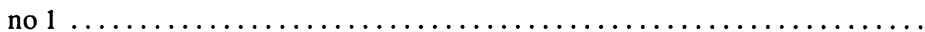


Parity Committee: Anachronistic or Futuristic? The, by Gérard P. Latulippe et

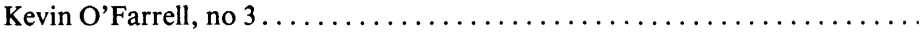

Part des salaires dans le revenu national au Canada, 1910 à 1980, La, Gérald

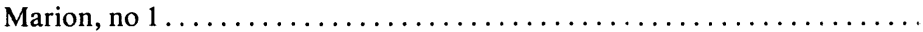

Partis politiques et croissance des syndicats au Canada, par Dennis R. Maki,

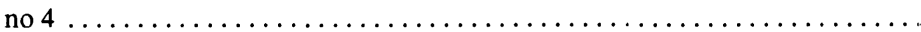

Pay Inequity and Public Policy in Canada and the U.S., Male-Female, by Naresh

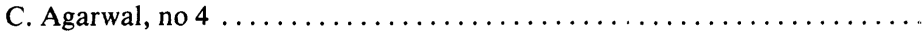

Pays européens, Le chômage, l'inflation et les travailleurs étrangers: étude comparative de trois, par Adolf Sturmthal, no $4 \ldots \ldots \ldots \ldots \ldots \ldots \ldots \ldots . . . \ldots \ldots$

Pluralisme syndical. Quelques données sur le Québec, La concurrence dans un

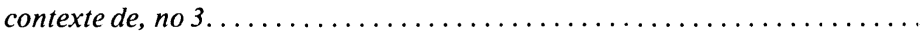

Political Parties and Trade Union Growth in Canada, by Dennis R. Maki, no 4 ...

Productivity Improvement Plan, The Canadair-I.A.M., by David A Peach,

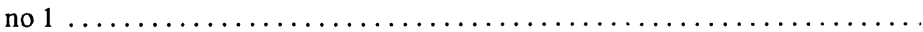

Professeurs d'université et leur travail, Les, par Jean-Yves LeLouarn, no 2 ......

Professional Engineers: A Canadian-American Comparison, Alienation Among,

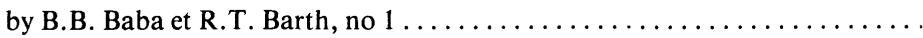

Public and Para-Public Sectors, Key Points of a Proposed Wage Policy for the,

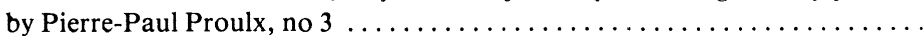

Public Policy in Canada and the U.S., Male-Female Pay Inequity and, by Naresh

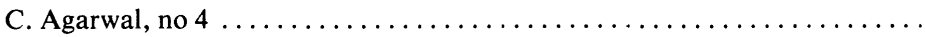

$780-802$

Québec Civil Service: An Empirical Study, Health of Office Workers in the, by Alain Vinet, Clermont Bégin et Gilles Thériault, no $4 \ldots \ldots \ldots \ldots \ldots \ldots$

904-905

Québec, La satisfaction au travail chez les enseignantes et enseignants $d u$, par Louis Toupin, Claude Lessard, Roger A. Cormier et Paul Valois, no 4 ......

$805-823$

Québec's Teachers, Work Satisfaction among, by Louis Toupin, Claude Lessard, Roger A. Cormier et Paul Valois, no $4 \ldots \ldots \ldots \ldots \ldots \ldots \ldots \ldots \ldots \ldots . \ldots \ldots$

Race and Sex Discrimination in Employment in Canada. Theories, Evidence and Politices, by Harish C. Jain, no 2 .

344-361

Race et sexe en tant qu'objet de discrimination dans l'emploi au Canada, par Harish C. Jain, no 2.

Reconnaissance des syndicats en Grande-Bretagne, La conciliation par une tierce

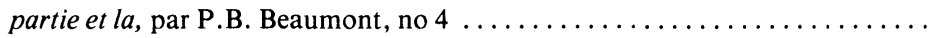

Recours individuel dans les secrétariats des Nations Unies, Les Voies de, par

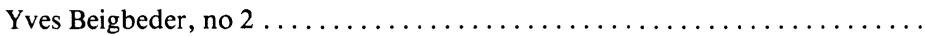

Régime québécois de négociation des secteurs public et para-public. Bilan et perspectives, Le, par Roch Bolduc, Lucien Bouchard et Gérard Hébert, no 2.... .

Relations professionnelles, Critique de la théorie des, par Syed M.A. Hameed,

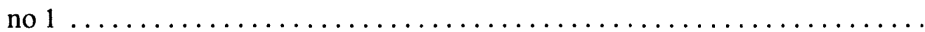

Relations professionnelles et les défis des années 80, Les, Francis Blanchard,

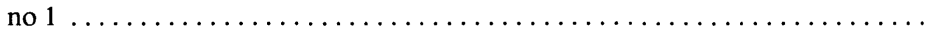

Relations professionnelles: une analyse paradigmatique, Les, par Stanley Young,

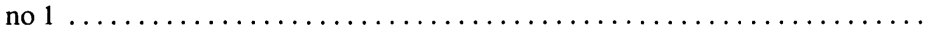

Rémunération dans les secteurs public et para-public au Québec. Éléments d'une nouvelle politique, par Pierre-Paul Proulx, no $3 \ldots \ldots \ldots \ldots \ldots \ldots$

Reservation Wages in Canadian Labour Markets, Abrar Hasan and Surendra

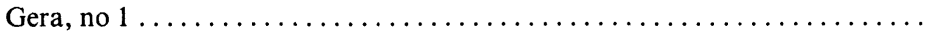

Rise of Industrial Unions in Montréal 1935-1945, The, by Terry Copp, no $4 \ldots . .$. Rise of Service Employment in the Canadian Economy, The, by Sunder Magun, no 3 
Role of Unions of Inflation: A Survey Article, The, by C.G. Williams, no 3 . . . .

Salaire d'acceptation sur les marchés du travail au Canada, Le taux de, par Abrar

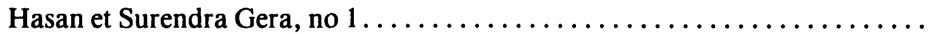

Salaires dans le revenu national au Canada, 1910 à 1980, La part des, Gérald

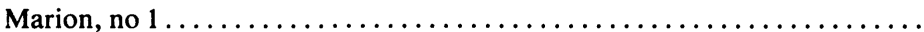

Santé des employés de bureau: le cas de la fonction publique québécoise, La, par Alain Vinet, Clermont Bégin et Gilles Thériault, no $4 \ldots \ldots \ldots \ldots \ldots \ldots$. . . . .

Satisfaction au travail chez les enseignantes et enseignants du Québec, La, par Louis Toupin, Claude Lessard, Roger A. Cormier et Paul Valois, no 4 ......

$805-823$

Secteurs public et para-public. Bilan et perspectives, Le régime québécois de négociation des, par Roch Bolduc, Lucien Bouchard et Gérard Hébert, no 2.....

$403-431$

Secteurs public et para-public au Québec. Éléments d'une nouvelle politique,

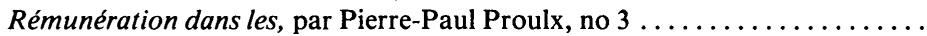

Services au Canada, L'augmentation de l'emploi dans les, par Sunder Magun, no 3

Service Employment in the Canadian Economy, The Rise of, by Sunder Magun, no 3

Specialist, A Macro/Micro Decision Model for the Training and Development, by David W. Mealia, no 3.

$656-668$

Spécialistes en formation et en développement, Un double modèle de décision

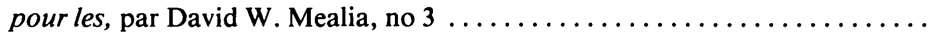

Stratégie syndicale face aux groupes semi-autonomes de production: hypothèse

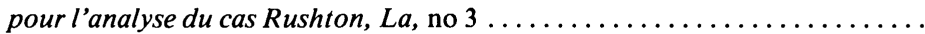

Strike Activity and Wildcat Strikes in British Columbia: 1945-1975, by E.G.

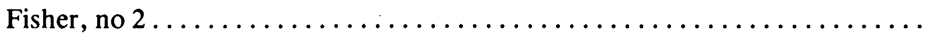

Strike Activity in Canada, 1926-1974, Legislative Change and, by J.A. Frank, Michael J. Kelly and Bruce D. Macnaughton, no $2 \ldots \ldots \ldots \ldots \ldots \ldots$

Strike, Ineffectiveness in Teacher Bargaining: The Anatomy of a First, by Philip Harris, Peter Rausch and Samuel G. Ryan, no $4 \ldots \ldots \ldots \ldots \ldots \ldots$

Syndicats au Canada, Parties politiques et croissance des, par Dennis R. Maki,

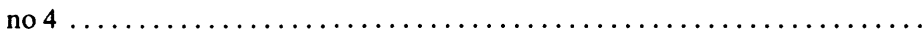

Syndicat d'enseignants, L'analyse de la première grève d'un, par Philip Harris,

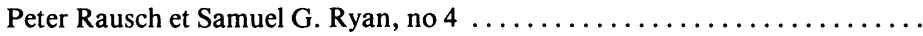

Syndicats et l'inflation, Les, par C.G. Williams, no $3 \ldots \ldots \ldots \ldots \ldots \ldots \ldots$

Syndicats industriels à Montréal de 1935 à 1945, Le développement des, par Terry

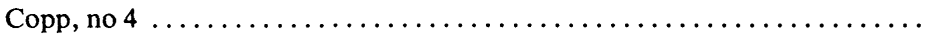

Syndicats, La femme et les postes de direction dans les, par Gary N. Chaison et

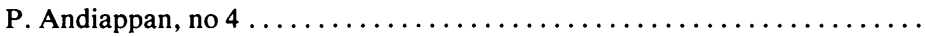

$668-670$

$670-684$

284-301

$267-281$

$905-926$

$885-887$

926-928

$526-528$

$875-876$

778-780

Système de gestion des cas du Conseil canadien des relations du travail, Le, par

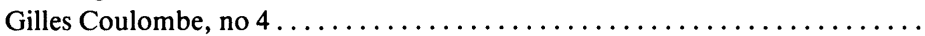

Taux d'activité de la main-d'oeuvre féminine et le statut matrimonial, Le, par

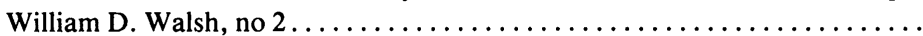

Taux de salaire d'acceptation sur les marchés du travail au Canada, Le, par Abrar

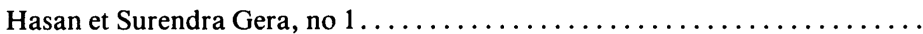

Teacher Bargaining: The Anatomy of a First Strike, Ineffectiveness in, by Philip Harris, Peter Rausch and Samuel G. Ryan, no $4 \ldots \ldots \ldots \ldots \ldots \ldots$

Teachers, Work Satisfaction Among Québec's, by Louis Toupin, Claude Lessard, Roger A. Cormier et Paul Valois, no $4 \ldots \ldots \ldots \ldots \ldots \ldots \ldots \ldots \ldots \ldots \ldots \ldots \ldots \ldots \ldots$

Third Party Conciliation and Trade Union Recognition: Some British Evidence,

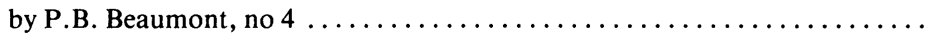


Tierce partie et la reconnaissance des syndicats en Grande-Bretagne, La concilia-

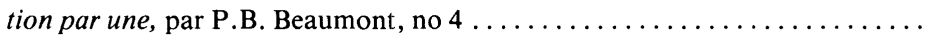

Time Series Analysis of Female Labour Force Participation Rates Disaggregated by Marital Status, $A$, by William D. Walsh, no $2 \ldots \ldots \ldots \ldots \ldots \ldots \ldots$

Trade Union Growth in Canada, Political Parties and, by Dennis R. Maki, no 4 . .

Trade Union Recognition: Some British Evidence, Third Party Conciliation and,

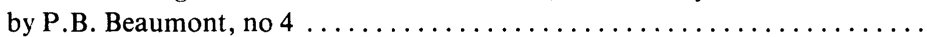

Training and Development Specialist, A Macro/Micro Decision Model for the,

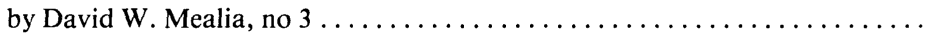

Travailleurs étrangers: étude comparative de trois pays européens, Le chômage, l'inflation et les, par Adolf Sturmthal, no $4 \ldots \ldots \ldots \ldots \ldots \ldots \ldots \ldots$

Tripartism, The Canadian Labour Congress and, by Anthony Giles, no $1 \ldots \ldots$.

Tripartism, The Federal Government and, by Roy J. Adams, no $3 \ldots \ldots \ldots \ldots$

Tripartisme, Le Congrès du travail du Canada et le, par Anthony Giles, no 1 .....

Tripartisme, Le gouvernement fédéral et le, par Roy J. Adams, no $3 \ldots \ldots \ldots$. ......

Unemployment, Inflation and "Guest Workers": Comparative Study of Three European Countries, by Adolf Sturmthal, no 4 .

606-617

$124-126$

$617-618$

Union Merger Process, A Note of the Critical Dimensions of the, by Gary N.

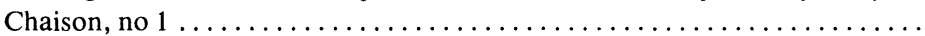

Union Officers in Canada, Characteristics of Female, by Gary N. Chaison and P.

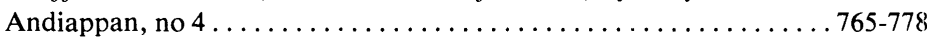

Unions in Inflation: A Survey Article, The Role of, by C.G. Williams, no 3 ....

United Nations Secretariats, Individual Grievance Procedures in, by Yves Beigbeder, no 2 .

$739-762$

198-206

$498-526$

328-342

University Professors Satisfied with their Jobs? Are, by Jean-Yves LeLouarn, no 2

U.S., Male-Female Pay Inequity and Public Policy in Canada and the, by Naresh

C. Agarwal, no 4

$402-403$

780-802

Voies de recours individuel dans les secrétariats des Nations Unis, Les, par Yves

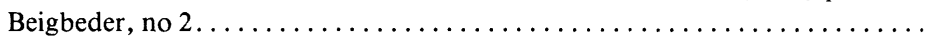

Wage Policy for the Public and Para-Public Sectors, Key Points of a Proposed, by

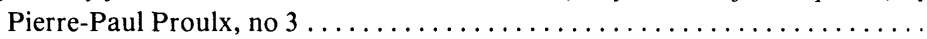

Wage Share in Canada, 1910-1980, The, Gérald Marion, no 1...............

Wages in Canadian Labour Markets, Reservation, Abrar Hasan and Surendra

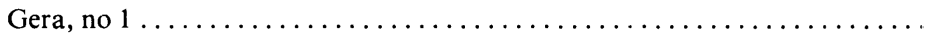

Wildcat Strikes in British Columbia: 1945-1975, Strike Activity and, by E.G.

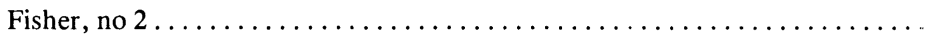

Work Satisfaction Among Québec's Teachers, by Louis Toupin, Claude Lessard, Roger A. Cormier et Paul Valois, no $4 \ldots \ldots \ldots \ldots \ldots \ldots \ldots \ldots \ldots \ldots \ldots \ldots \ldots \ldots \ldots$

\section{Index de la juridiction du travail}

\section{Décisions rendues par le Conseil canadien des relations du travail}

Accréditation appropriée et la règle de «l'ultra petita», L'unité d', no $3 \ldots \ldots \ldots$. 
Élargissement de l'unité et les droits des nouveaux employés, $L$ ', no $3 \ldots \ldots \ldots . .$.

Employés en période de probation et le droit à l'arbitrage, Les, no $2 \ldots \ldots \ldots \ldots$

"Employé» sous le Code canadien du travail, La notion d', no $4 . . . . . . . . . . .$.

944-959

Gel statutaire de l'article 148) du Code, Le, no $2 \ldots \ldots \ldots \ldots \ldots \ldots \ldots \ldots . . . \ldots \ldots$

443-449

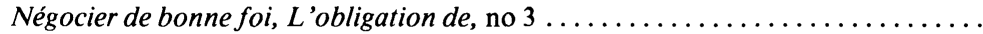

692-696

Notion d'«employé» sous le Code canadien du travail, La, no $4 \ldots \ldots \ldots \ldots \ldots$

$944-959$

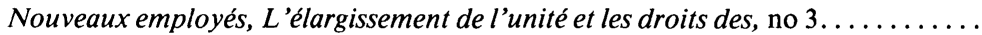

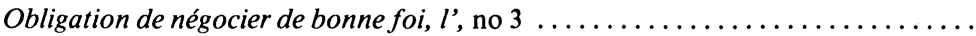

Probation et le droit à l'arbitrage, Les employés en période de, no $1 . . . . . . . .$.

Représentation juste et équitable dans le cadre de la négociation, no $1 \ldots \ldots \ldots . .$.

Syndicat-employeur et ses cadres supérieurs et officiers, Le, no $1 \ldots \ldots \ldots \ldots \ldots$

Unité d'accréditation appropriée et la règle de «l'ultra petita», $L$ ', no $3 \ldots \ldots \ldots$.

Unité et les droits des nouveaux employés, $L$ 'élargissement de $l$ ', no $3 \ldots \ldots \ldots . .$.

Ultra petita, L'unité d'accréditation appropriée et la règle de l', no $3 \ldots \ldots \ldots \ldots$

Changements dans les législations du travail au Canada

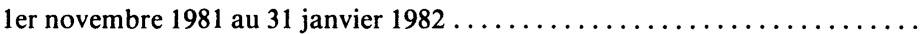

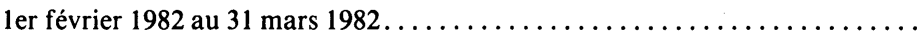

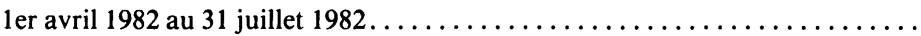

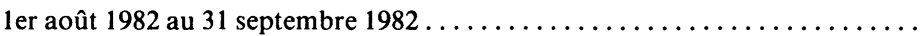

688-692

692-696

438-443

226-229

230-234

684-688

688-692

684-688

235-239

451-453

697-703

960-962

\section{Auteurs des ouvrages recensés}

ARTHURS, H.W., Labour Law and Industrial Relations in Canada, (Pierre

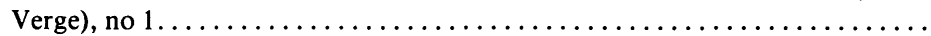

BAUM, Gregory, The Priority of Labor. A Commentary on Laborem exercens,

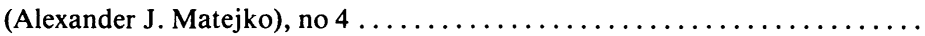

BOISVERT, Maurice, La qualité de la vie vie au travail, (Lucie Vézina), no 3.....

BOIVIN, Jean, Les relations patronales-syndicales au Québec, (Dimitri Weiss),

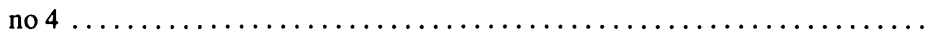

969-970

BOULET, Jac-André, La langue et le revenu du travail à Montréal, (Jean-Marie Rainville), no 4.

971-973

CARTER, D.D., Labour Law and Industrial Relations in Canada, (Pierre Verge), no 1

$241-243$

CARVEN, Paul, 'An Impartial Umpire': Industrial Relations and the Canadian State 1900-1911, (James Thwaites), no 1.....................

CNRS (éd.) L'évolution des systèmes de travail dans l'économie moderne, (Gérard

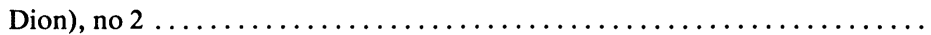

CONNAGHAN, Charles J., L'expérience japonaise: relations industrielles $d u$

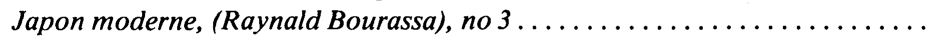

CONSEIL ÉCONOMIQUE DU CANADA, Pénuries et carences. Travailleurs qualifiés et emplois durant les années 80 , (Gérard Bélanger), no $3 \ldots \ldots \ldots$

COPP, Terry, Working People, An Illustrated History of Canadian Labour,

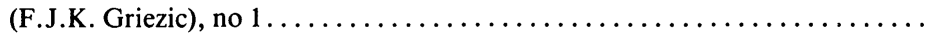

$252-253$

460

720

704-709

243-245

COUSINEAU, Jacques, L'Église d'ici et le social 1940-1960, (Gérard Dion),

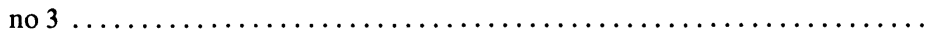

CUMMINGS, Thomas G., Improving Productivity and the Quality of Work Life,

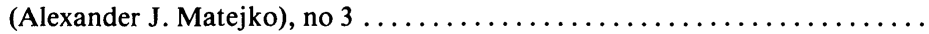

DELPLANQUE, Bernard, Le partage de l'emploi, vers une société sans chômage,

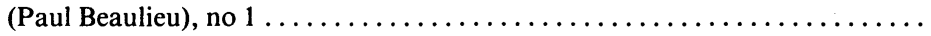


DEMERS, François, Chroniques impertinentes du 3ième (sic) Front commun syndical, 1979-1980, (Gérard Hébert), no 4 ......................

DENTON, F.T., Unemployment and Labour Force Behaviour of Young People: Evidence from Canada and Ontario, (Jacques Mercier), no 1 ............

FOSSUM, John A., Labor Relations: Development, Structure, Process, (Kurt

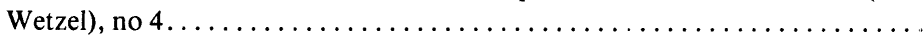

FRIEDMAN, Henry, The Dynamics of Industrial Conflict, Lessons from Ford,

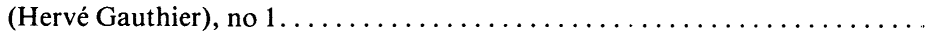

GLASBECK, H.J., Labour Law and Industrial Relations in Canada, (Pierre

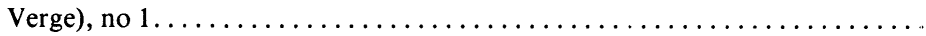

GLUECK, William F., Personnel: A Diagnostic Approach, (Laurent Bélanger),

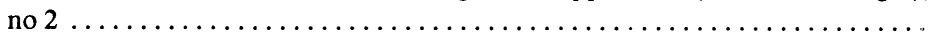

GUILBAULT, Jacques, Les relations patronales-syndicales au Québec, (Dimitri

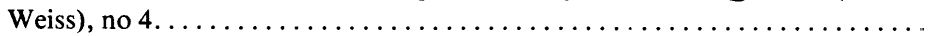

HOUDE, Eugène, Émotivité et efficacité au travail, (Bernard Angers), no 2.....

INFANTE, Jaime T., The Political Economic and Labor Climate in the Philippi-

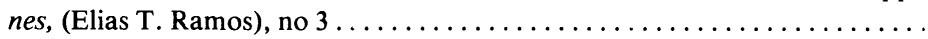

JACKSON, John H., Organization Theory: A Macro Perspective for Manage-

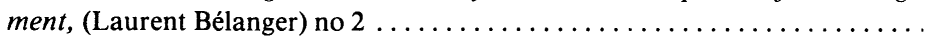

KAHN-FREUND, O., Labour Law and Politics in the Weimar Republic, (Pierre Verge), no 2 .

454-455

MARIC, D., La durée du travail dans les pays en voie de développement, (Alain Larocque), no 3

MARSH, Arthur, Historical Directory of Trade Unions, (Gérard Dion), no 1 . . . .

MCCARTHY, Maureen, Work Sharing: Case Studies, (Alain Vinet), no $4 \ldots \ldots$. .

MCGAUGHEY, William, A Shorter Workweek in the 1980's, (Alain Larocque), no 3

245-246

971-971

$718-719$

MELTZ, Noah, Sharing the Work: An Analysis of the Issues in Worksharing and Jobsharing, (Paul Blyton), no 3 . .

$717-718$

MEREDEEN, Sander, The Dynamics of Industrial Conflict Lessons from Ford, (Hervé Gauthier), no 1.

$246-248$

MOLLOY, Edmond S., Improving Productivity and the Quality of Work Life, (Alexander J. Matejko), no 3 ...

MORGAN, Cyrill P., Organization Theory: A Macro Perspective for Management, (Laurent Bélanger), no 2..............................

MORTON, Desmond, Working People, An Illustrated History of Canadian

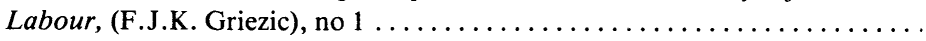

NADEAU, Gaston, Le statut juridique du salarié - gréviste québécois, (Rodrigue

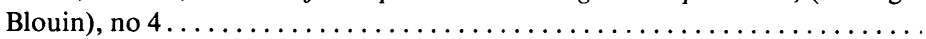

REID, Frank, Sharing the Work: An Analysis of the Issues in Worksharing and Jobsharing, (Paul Blyton), no 3 ...

ROBB, A.L., Unemployment and Labour Force Behaviour of Young People: Evidence from Canada and Ontario, (Jacques Mercier), no $1 \ldots \ldots \ldots \ldots$.

ROSENBERG, Gail S., Work Sharing: Case Studies, (Alain Vinet), no 4 .......

RYAN, Victoria, Historical Directory of Trade Unions, (Gérard Dion), no $1 . .$. .

SIEGEL, Irving H., Labor-Management Cooperation. The American Experience, (Jean Sexton), no 4.

$457-458$

$243-245$

$966-967$

$717-718$

$249-251$

971-971

245-246

973-973

SPENCER, B.G., Unemployment and Labour Force Behaviour of Young People: Evidence from Canada and Ontario, (Jacques Mercier), no $1 \ldots \ldots \ldots \ldots$.

STOREY, John, The Challenge to Management Control, (Jacques Bélanger),

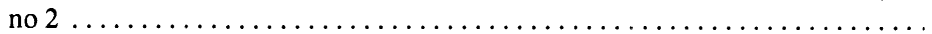


SWATZ, Gerald S., Sharing the Work: An Analysis of the Issues in Worksharing and Jobsharing, (Paul Blyton), no $3 \ldots \ldots \ldots \ldots \ldots \ldots \ldots \ldots \ldots \ldots \ldots \ldots \ldots$

$717-718$

VAISEY, Douglas G., The Labour Companion: A Bibliography of Canadian Labour History, based on Materials Printed from 1950 to 1975, (Mario

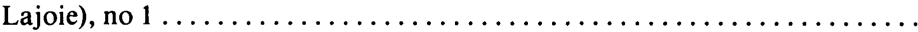

$251-252$

VIGEANT-GALLEY, Paulette, Les enseignants et le pouvoir: histoire de l'Alliance des professeurs de Montréal, les luttes syndicales et le développement social (1952-1958), (James Thwaites), no $3 \ldots \ldots \ldots \ldots \ldots \ldots \ldots \ldots$

WEINBERG, Edgar, Labor-Management Cooperation. The American Experience, (Jean Sexton), no $4 \ldots \ldots \ldots \ldots \ldots \ldots \ldots \ldots \ldots \ldots \ldots \ldots \ldots \ldots \ldots \ldots \ldots \ldots \ldots$

WOODS, H.D., Relations industrielles dans l'industrie de la construction du sud du Nouveau-Brunswick/Southern New Brunswick Construction Industry Industrial Relations, (Jean Sexton), no $1 \ldots \ldots \ldots \ldots \ldots \ldots \ldots \ldots \ldots \ldots$

***Index et résumés de sentences arbitrales de griefs, vol. 1, 1970-1980, no 4 . . . .

967-968

\section{Auteurs d'articles}

ADAMS, Roy J., The Federal Government and Tripartism, no 3 ............

AGARWAL, Naresh C., Male-Female Pay Inequity and Public Policy in Canada

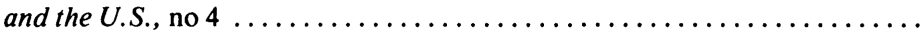

ANDIAPPAN, P., Characteristics of Female Union Officers in Canada, no 4 ....

BABA, V.V., Alienation Among Professional Engineers: A Canadian-American

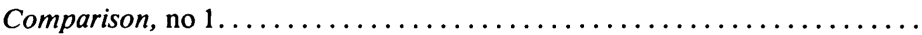

BABA, Vishwaneth V., The Nature of Need Structure in Nonwork, no 3 ........

BARTH, Richard T., Alienation Among Professional Engineers: A Canadian-

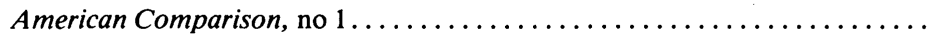

BEAUMONT, P.B., Third Party Conciliation and Trade Union Recognition:

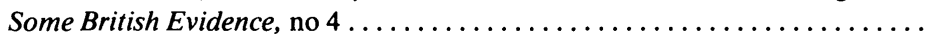

BÉGIN, Clermont, La santé des employés de bureau: le cas de la fonction publi-

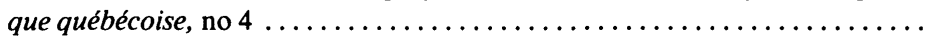

$887-905$

BEIGBEDER, Yves, Individual Grievance Procedures in United Nations

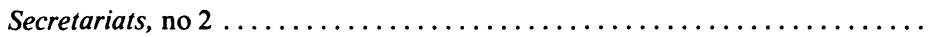

BLANCHARD, Francis, Les relations professionnelles et les défis des années 80,

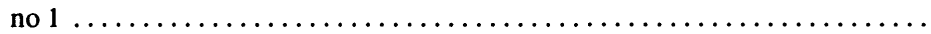

328-344

BOLDUC, Roch, Le régime québécois de négociation des secteurs public et parapublic. Bilan et perspectives, no 2

403-411

BOUCHARD, Lucien, Le régime québécois de négociation des secteurs public et para-public. Bilan et perspectives. À quand la maturité? no $2 \ldots \ldots \ldots \ldots$

BROSSARD, Michel, La stratégie syndicale face aux groupes semi-autonomes de production: hypothèse pour l'analyse du cas Rushton, no $3 . \ldots \ldots \ldots \ldots$

CHAISON, Gary N., A note of the Critical Dimensions of the Union Merger

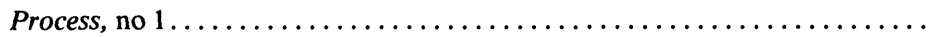

CHAISON, Gary N., Characteristics of Female Union Officers in Canada, no 4 ..

CHOUINARD, Jacques, L'efficacité des clauses d'indexations des salaires,

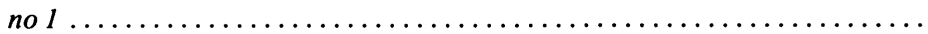

CHOUINARD, Jacques, L'efficacité des clauses d'indexations des salaires,

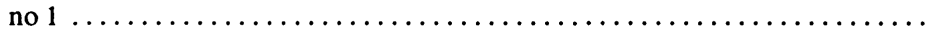

COPP, Terry, The Rise of Industrial Unions in Montréal 1935-1945, no 4.......

CORMIER, Roger A., La satisfaction au travail chez les enseignantes et ensei-

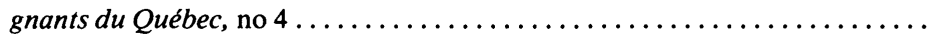

$411-420$

$670-684$

198-206

765-780

207-214

220-224

843-876

805-827 
COULOMBE, Gilles, Le système de gestion des cas du Conseil canadien des rela.

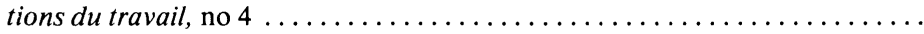

COUSINEAU, Jean-Michel, L'efficacité des clauses d'indexation des salaires,

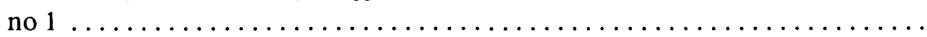

DEOM, Esther, La négociation collective chez les fonctionnaires et les enseignants

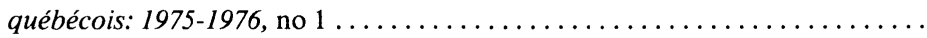

DELORME, François, La concurrence dans un contexte de pluralisme syndical.

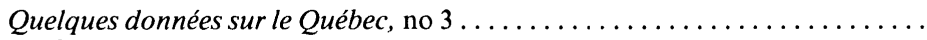

DESCHÊNES, Jean-Paul, L'évaluation des emplois et la convention collective,

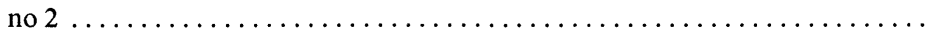

FISHER, E.G., Strike Activity and Wildcat Strikes in British Columbia: 1945.

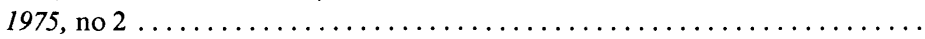

FRANK, J.A., Legislative Change and Strike Activity in Canada, 1926-1974,

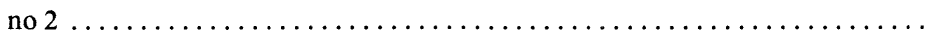

GERA, Surendra, Reservation Wages in Canadian Labour Markets, no 1.......

GILES, Anthony, The Canadian Labour Congress and Tripartism, no $1 . . . \ldots$.

HAMEED, Syed M.A., A Critique of Industrial Relations Theory, no $1 . \ldots \ldots$. .

HARRIS, Philip, Ineffectiveness in Teacher Bargaining: The Anatomy of a First

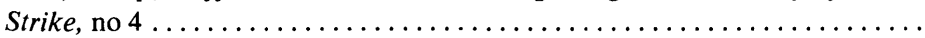

HASAN, Abrar, Reservation Wages in Canadian Labour Markets, no 1 .........

HÉBERT, Gérard, Le régime québécois de négociation des secteurs public et parapublic. Bilan et perspectives. Réflexions, no $2 \ldots \ldots \ldots \ldots \ldots \ldots \ldots \ldots \ldots$

JAIN, Harish C., Race and Sex Discrimination in Employment in Canada.

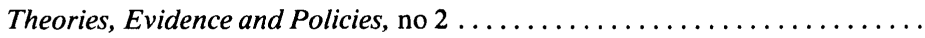

JAMAL, Muhammad, The Nature of Need Structure in Nonwork, no $3 . . . . .$. KELLY, Michael J., Legislative Change and Strike in Canada, 1926-1974, no 2 . . . LACROIX, Robert, $L$ 'efficacité des clauses d'indexations des salaires, no $1 . . .$. . LAFRANCE, Victor, La concurrence dans un contexte de pluralisme syndical.

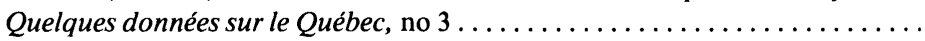

LATULIPPE, Gérard P., Le comité paritaire: anachronisme ou formule d'avenir,

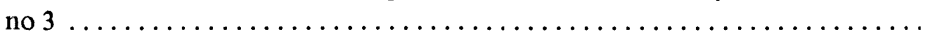

LE LOUARN, Jean-Yves, Les professeurs d'université et leur travail, no $2 . . .$. .

LESSARD, Claude, La satisfaction au travail chez les enseignantes et enseignants

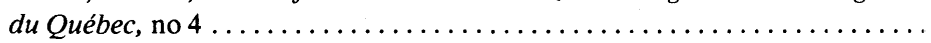

MACNAUGHTON, Bruce D., Legislative Change and Strike in Canada, 1926-

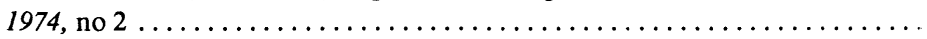

905-927

$267-284$

MAGUN, Sunder, The Rise of Service Employment in the Canadian Economy, no 3 ...........................................

MAKI, Dennis R., Political Parties and Trade Union Growth in Canada, no 4....

MARION, Gérald, La part des salaires dans le revenu national au Canada, 1910 à

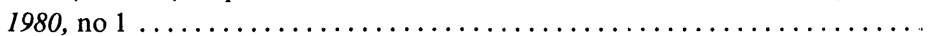

MEALIA, David W., A Macro/Micro Decision Model for the Training and Development Specialist, no 3 ...

528-557

876-887

MELTZ, Noah, Labour Market Information in Canada. The Current Situation

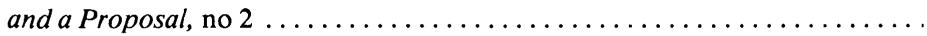

MICHAUD, Sharon, L'efficacité des clauses d'indexations des salaires, no $1 . .$. .

MILLER, Roger, Les formes d'organisation dans l'industrie de la construction,

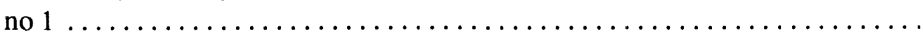

MITCHELL, Vance F., The Nature of Need Structure in Nonwork, no 3 .......

O'FARRELL, Kevin, Le comité paritaire: anachronisme ou formule d'avenir, no 3 
PEACH, David A., The Canadair-I.A.M. Productivity Improvement Plan,

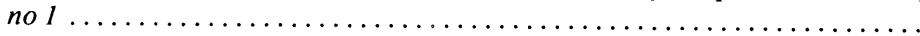

PROULX, Pierre-Paul, Rémunération dans les secteurs public et para-public au

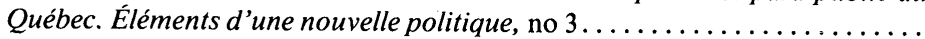

RAUSCH, Peter, Ineffectiveness in Teacher Bargaining: The Anatomy of a First

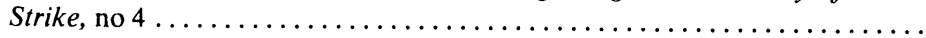

ROBICHAUD, Jean-Maric, L'efficacité des clauses d'indexations des salaires,

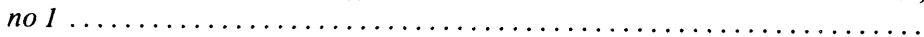

ROY, Jean-Charles, L'efficacité des clauses d'indexations des salaires, no $1 . . . .$.

RYAN, Samuel G., Ineffectiveness in Teacher Bargaining: The Anatomy of a

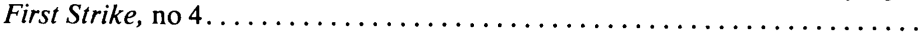

STURMTHAL, Adolf, Unemployment, Inflation and "Guest Workers": Compa-

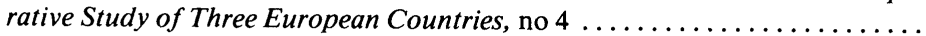

THÉRIAULT, Gilles, La santé des employés de bureau: le cas de la fonction pu-

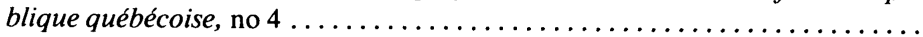

TOUPIN, Louis, La satisfaction au travail chez les enseignantes et enseignants

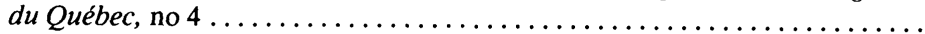

VALOIS, Paul, La satisfaction au travail chez les enseignantes et enseignants $d u$

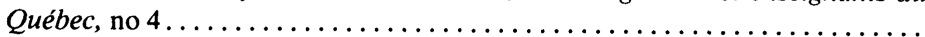

VIEL, André, L'efficacité des clauses d'indexations des salaires, no $1 \ldots \ldots \ldots$.

VINET, Alain, La santé des employés de bureau: le cas de la fonction publique québécoise, no 4 .

WALSH, William D., A Time Series Analysis of Female Labour Force Participation Rates Disaggregated by Marital Status, no $2 \ldots \ldots \ldots \ldots \ldots \ldots \ldots$

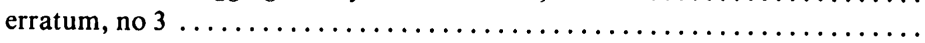

WEIERMAIR, Klaus, Apprenticeship Training in European Countries. The

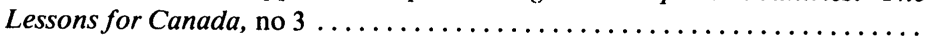

\section{INDUSTRIAL RELATIONS JOURNAL} INDUSTRIAL RELATIONS RESEARCH \& PUBLICATIONS UNIT DEPARTMENT OF ADULT EDUCATION UNIVERSITY OF NOTTINGHAM, UNIVERSITY PARK NOTTINGHAM NG7 2RD

Editor: Brian Towers

\section{Some forthcoming articles:}

The wildcat strike and industrial relations - a participant-observer study of a US Plant

Democracy from the inside - a comparative analysis of the engineering workers' trade unions in Australia and the UK

Strikes in four EEC countries - a study of France, West Germany, Italy and the UK

Developments in French industrial relations

Industrial Relations in Denmark

Issued quarterly. Institutional subscription $£ 25$ per year, overseas $£ 34$ (US \$65), individual subscription $£ 22.50$, overseas $£ 30$ (US $\$ 60$ ), single copies $£ 7.50$, overseas $£ 10$ (US \$20). Agency commission $10 \%$. Cheques payable to Industrial Relations Journal. 